\title{
Hemşirelerin Kişisel Değerleri ile Etik Duyarlııkları Arasındaki İlişkinin Belirlenmesi
}

\author{
Determining The Relationship Between Nurses Personal Values and Their Ethical \\ Sensitivity
}

\author{
Berna KÖKTÜRK DALCALI*, Merdiye ŞENDİR**
}

İletişim/Correspondence: Berna KÖKTÜRK DALCALI Adres/ Address: Karabük Üniversitesi, Safranbolu Meslek Yüksekokulu, 78600, Safranbolu-KARABÜK Tel: 037043382 00/ 5063 Fax: 03707254003 E-mail: bernakokturk@karabuk.edu.tr

\begin{abstract}
$\ddot{O} Z$
Amaç: Çalışma hemşirelerin kişisel değerleri ve etik duyarlılık düzeylerini belirlemek, aralarındaki ilişkiyi incelemek amacıyla yapildi.

Yöntem: Araştırma tanımlayıcı-ilişki arayıcı olarak yapıldı. Araștırma için Kocaeli Üniversitesi Tıp Fakültesi Etik Kurulu'ndan ve araştırmanın yürütüleceği kurumlardan yazılı izinler alındı. Araştırmanın evrenini Yalova ilinde iki özel hastane ve iki devlet hastanesinde çalıșmakta olan 230 hemsire, araștırmanın örneklemini ise çalıșmaya kabul eden 170 hemșire oluşturdu. Verilerin toplanmasında "Yapılandırılmış Soru Formu", "Değerler Hiyeraraşisi Ölçeği (DHÖ)" ve "Ahlaki Duyarlılık Anketi (ADA)" kullanıldı. Verilerin analizi, bilgisayarda SPSS 15.0 paket programı kullanılarak frekans, yüzde, ortalama, standart sapma, çapraz tablolar, Mann-Whitney U testi ve Kruskall Wallis testi ile yapild .

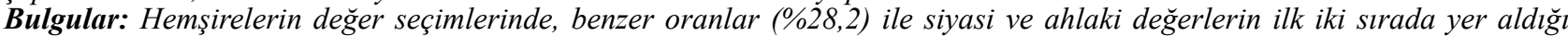

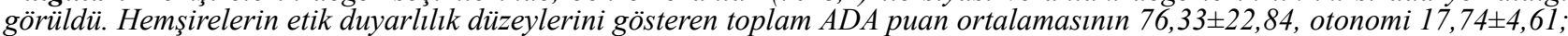

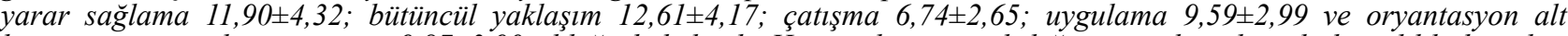

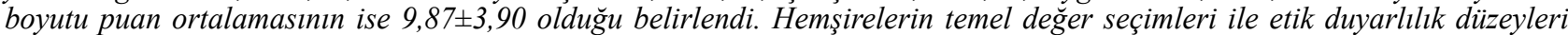
karşılaştırıldığında; sosyal değerleri benimseyen hemşirelerin tüm boyutlarda daha düşük puan aldığı görüldü. Hemşirelerin kişisel değerleri ile etik duyarlılıkları arasında ilişki olduğu saptandı $(p<0.05)$.

Sonuç: Hemşirelerin siyasi ve ahlaki değerleri öncelikli olarak benimsediği saptandı. Etik duyarlılık düzeylerinin iyi olduğu ve kişisel de ğer seçiminin etik duyarlılık düzeyini etkilediği belirlendi.

Anahtar Kelimeler: Etik duyarlılık, kişisel değerler, hemşirelik, etik.

\section{ABSTRACT}

Aim: The study was performed as descriptive, comperative and correlational to evaluate the personal values and ethical sensitivity level of the nurses and to examine the relation in-between.

Method: The study was performed as descriptive, comperative and correlational. Written permissions are obtained from Kocaeli University, Faculty of Medicine ethic committee and the insitutions that will carry out this research. The universe of the research consists of 230 nurses working at two private hospitals and two public hospitals in Yalova City; the sample of the research consists of 170 nurses who accept to work for this research.

The data of the research were collected by using "Structured Questionnaire", "Hierarchy of Values Scale" and "Moral Sensitivity Questionnaire-MSQ" and analysed with frequency, percentage, average, standard deviation, crosstabs, Mann Whitney U and Kruskall Wallistest by using SPSS-15 package programme on computer.

Results: Among the value choices of the nurses, political and moral values ranked first and second with similar percentage among the nurses in the sample (\%28,2). Nurses' ADA total $(X \pm \mathrm{SS} 76,33 \pm 22,84)$ and its sub-dimensions (autonomy is 17,74 $\pm 4,61$;

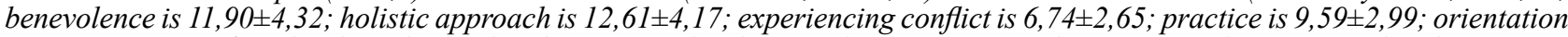

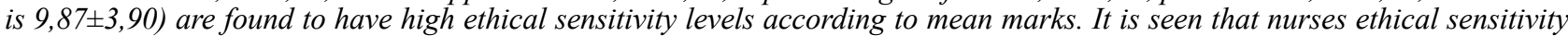
levels differ according to their basic personal value preferences. The findings show that nurses who adopt social values as their basic value have high ethical levels and nurses who adopt economic values as their basic value have the lowest ethical sensitivity level.

Conclusion: In conclusion, it is detected that nurses adopted primarily political and moral values. It is determined that ethical sensitivity levels vary according to nurses basic personal value preferences.
\end{abstract}

Keywords: Ethical sensitivity, personal values, nursing, ethics.

*Öğr. Gör. Karabük Üniversitesi, Safranbolu Meslek Yüksekokulu, **Prof. Dr. İstanbul Üniversitesi, Florence Nightingale Hemşirelik Fakültesi

Yazının gönderilme tarihi: 02.09.2015

Yazının basım için kabul tarihi: 29.01.2016 


\section{GíRIŞ}

İnsanlar arasındaki ilişkilerin temelinde yer alan değerleri, ahlaki bakımdan iyi ya da kötü, doğru ya da yanlış olanın niteliğini araştıran bir felsefe dalı olarak etik, son yıllarda hemşirelikte önem kazanmaktadır (Acaroğlu 2003; Cherie, Mekonen ve Shimelse 2005). Çünkü hemşirelik, sağlıkl1/hasta bireyi bütüncül yaklaşımla ele alarak ailesi, yakın ve geniş çevresiyle birlikte değerlendiren hümanistik ve holistik bakım felsefesine odaklanır (Acaroğlu ve Şendir 2012; Karaöz 2000; Şendir 2012). Bakım, hastanın değerleri ve beklentileri ile hemşirenin kendi değer ve ödevlerinin çatışması için uygun bir süreçtir ve bakım esnasında yaşanan bu çatışmalar etik ikilemlerin nedenini oluşturur (Acaroğlu 2003; Aitamaa, Leino-Kilpi, Puukka ve Suhonen 2010). Bireyin benimsediği, hissettiği ya da taşıdığı değerler hem doyum hem de çatışma kaynağıdır. Bireyin taşıdığı değerler aynı zamanda kişisel gereksinimlerini, sosyal etkilerini ve başkaları ile olan ilişkilerini de etkiler (Altun 2001). Değerler, olması gerekene ilişkin ve davranışlara rehberlik eden inanç ve tutumlardır (Cozma 2011; Korkmaz-Devrani 2010; Ochsner 1996).

Bilim ve teknolojideki ilerlemelerin birtakım değer sorunlarının ortaya çıkışına neden olması sağlık alanında etiğin önemini arttırmaktadır. Sağlık bakım sisteminde genişleyen rol ve sorumlulukları gereği bilimsel bilgi içeriği de gittikçe artan hemşireler, etik ikilemlerle sıklıkla karşı karşıya gelmekte ve etik problemleri çözümlemek durumunda kalmaktadır (Aslan, Vural ve Avc1 2003; Dinç ve Görgülü 2002; Karaöz 2000; Noureddine 2001). Etik ikilem; iki ya da daha fazla seçenek arasında kalındığında hangi seçeneğin daha iyi olduğuna karar verme güçlüğü yaşandığında ve mevcut olan alternatiflerin gereksinmeleri çözmeye yetmediği durumlarda ortaya çıkar (Elçigil ve ark. 2011). Hemşirelerden karşılaştıkları bu etik ikilemler karşısında doğru karar verebilmeleri beklenmektedir. Ancak hemşirelerin, etik problemleri tanıması ve çözümleyebilmesi konusunda doğru kararları alabilmesi için, etik sorunu ayırt edebilme yeteneği olarak tanımlanan etik duyarlılıklarının ge- lişmiş olması gerekmektedir (Aksu ve Akyol 2011). Etik duyarlılık çelişkilerle dolu durumlarda ahlaki değerler ya da kişinin var olan durum içinde kendi rol ve sorumluluklarının farkına varması olarak tanımlanır (Pekcan 2007; Tosun 2005). Etik duyarl1l1k eğitim ile geliştirilir, mesleki yeterliliği sürdürme ve mesleğin etik kodlarına uygun davranışları sergilemek ile devam ettirilir (Aksu ve Akyol 2011; Pekcan 2007). Etik ikilem bir eylem sirasında karar verilmesi gereken bir durumda iki değer arasındaki karmaşadan kaynaklanır (Fry, Veatch ve Taylor 2010). $\mathrm{Bu}$ durumda etik ikilemin farkedilebilmesi ve çözülebilmesi için gerekli olan etik duyarlılık bakım veren hemşirenin kendi kişisel değerlerinden etkilenir. Karar verme sürecine katkıda bulunan temel unsurlar olan kişisel değerlerin tanımlanması, davranışların daha açık olarak anlaşılmasını sağlar (Keskin ve Yıldırım 2006). Bu nedenle hemşirelerin kendi değerlerinin farkında olması ve bunların insan davranışlarını nasıl etkilediğini bilmesi, hastalarına daha duyarlı bir bakım vermesine yardımcı olacaktır (Karaöz 2000). Hemşirelik uygulamasında etik bir bakım hemşirelerin kendi değerlerini bilmeyi ve bu değerleri uygun şekilde kullanmayı gerektirir (Jormsri, Kunaviktikul, Ketefian ve Chaowalit 2005). Literatür incelendiğinde hemşirelerin sıklıkla etik ikilemlerle yüz yüze kaldığı bu etik ikilemlerin karar verme, aydınlatılmış onam, kardiyopulmoner resüsitasyon, yaşam desteğinin kısıtlanması ve sonlandırılması, tıbbi kaynakların adil dağıtımı gibi çeşitli konularda yaşandığ1 görülmüştür (Tel 2012). Hemşirelerin karş1laştıkları etik ikilemlerin fark edilebilmesi ve çözülmesinde profesyonel sorumlulukları ve kişisel değerleri arasında kaldığına vurgu yapılmasına karşın kişisel değerlerin etik duyarlılık ve bakıma olan yansımalarını ortaya koyan bir çalışmaya rastlanmamıştır (Casterle, Izumi, Godfrey ve Denhaerynck 2008; Schneider ve Ramos 2012; Volker 2003). Bu nedenle çalışma; hemşirelerin etik duyarlılıklarını etkilediği düşünülen kişisel değerlerini belirleme ve kişisel değerlerine göre etik duyarlılık düzeylerini ortaya koymak amacıyla yapıldı. 


\section{YÖNTEM}

\section{Araştırmanın Amacı ve Tipi}

$\mathrm{Bu}$ çalışma hemşirelerin kişisel değerleri ile etik duyarlılık düzeylerini belirleyerek aralarındaki ilişkiyi incelemek amacı ile tanımlayıcı-ilişki arayıcı tipte yapildi.

\section{Araştırma Soruları}

- Hemşirelerin sahip oldukları kişisel değerleri ve etik duyarlı1ık düzeyleri nasıldır?

- Hemşirelerin kişisel değerlerini etkileyen faktörler nelerdir?

- Hemşirelerin sahip oldukları kişisel değerler ile etik duyarlılıkları arasında bir ilişki var mıdır?

\section{Araştırmanın Evreni ve Örneklemi}

Araştırmanın evrenini Yalova ilinde devlet ve özel hastanelerde çalışmakta olan 230 hemşire oluşturdu. Araştırmanın örneklemini ise tam sayım yöntemi ile çalışmayı kabul eden 170 hemşire oluşturdu. Çalışmay1 kabul eden hemşireler evrenin \%73,1'ini oluşturdu ve çalışma Aralık 2012-Şubat 2013 tarihleri arasında gerçekleştirildi.

\section{Veri Toplama Araçları}

Verilerin toplanmasında Yapılandırılmış Soru Formu, Değerler Hiyeraraşisi Ölçeği (DHÖ) ve Ahlaki Duyarlılık Anketi (ADA) kullanıldı.

Yapılandırılmış Soru Formu: Araştırmacı tarafindan, literatür bilgisi doğrultusunda hazırlanan soru formunda; yaş, cinsiyet, medeni durum, öğrenim durumu gibi hemşirelerin sosyodemografik özelliklerine ilişkin 7 soru, çalıştıkları bölüm, görevleri, etik ve değerler konusunda eğitim alma, mesleki dernek üyeliği gibi mesleki özelliklerine ilişkin 6 soru, sivil toplum kuruluşu üyeliği, arkadaşlarla istenilen sıklıkta görüşme ve düzenli sosyal aktivite sürdürme durumlarına ilişkin 3 soru ile toplamda 16 kapalı uçlu soruya yer verildi (Güngör 1998; Pekcan 2007; Tosun 2005).

Değerler Hiyeraraşisi Ölçeği-DHÖ: Hemşirelerin değer tercihlerini belirleyebilmek amaciyla Allport,
Vernon ve Lindzey (1960)' in 6 değer boyutuna Güngör (1998)'ün ahlaki değer boyutunu da ekleyerek geliştirmiş olduğu Değerler Hiyerarşisi Ölçeği (DHÖ) kullanıldı. DHÖ’nde; estetik, ahlaki, teorik, iktisadi, dini, siyasi ve sosyal olmak üzere toplamda 7 değer alan1na ait toplam 14 ifade bulunmaktadır (Tablo 1). Hemşirelerden bu alanlarda yer alan ifadeleri kendilerine göre önem sırasına (1-14 arası) koymaları istenmektedir. Güngör (1998) tarafından geliştirilen ölçeğim Cronbach Alpha katsayısı 0.84 olarak bulunmuştur.

Tablo 1. Değer Tercihleri İfadeleri ve Değer Türleri

\begin{tabular}{|l|l|}
\hline Değer Türü & İfadeler \\
\hline Estetik Değerler & Her şeyin ölçülü ve ahenkli olması \\
\cline { 2 - 2 } & Güzelliklerle dolu bir dünya \\
\hline \multirow{2}{*}{ Ahlaki Değerler } & Yalansız bir dünya \\
\cline { 2 - 2 } & Vicdan huzuru \\
\hline Teorik Değerler & Bütün gerçeklerin bilinmesi \\
\cline { 2 - 2 } & Cahillikten arınmış bir dünya \\
\hline \multirow{2}{*}{ İkisadi Değerler } & Ekonomik bağımsızlık \\
\cline { 2 - 2 } & Konforlu bir hayat \\
\hline \multirow{2}{*}{ Dini Değerler } & Öbür dünyayı kazanmak \\
\cline { 2 - 2 } & Günahlardan arınma \\
\hline Siyasi Değerler & Eşitliğin sağlanması \\
\cline { 2 - 2 } & Hürriyet için mücadele \\
\hline Sosyal Değerler & Gerçek dostluk \\
\cline { 2 - 2 } & İnsanlara yardım \\
\hline
\end{tabular}

Ahlaki Duyarlılı Anketi-ADA; Kim Lützen tarafindan geliştirilen Ahlaki Duyarlılık Anketi (ADA), 1994 y1lında öncelikle Karolinska Hemşirelik Enstitüsü'nde (İsveç-Stockholm) psikiyatri kliniğindeki, sonra da diğer birimlerde çalışan hekim ve hemşirelerin etik karar verme sürecinde gösterdikleri etik duyarlılığı belirlemek amaciyla kullanıldı (Lützen, Johansson ve Nordström 2000; Tosun 2005). ADA toplam 30 madde ve 6 alt boyuttan (otonomi, yarar sağlama, bütüncü yaklaşım, çatışma, uygulama, oryantasyon) oluşan 7'li likert tipte bir ölçüm aracıdır. ADA'dan alınabilecek en düşük puan 30, en yüksek puan 210 'dur. Düşük puan etik açıdan 
yüksek duyarlılı̆̆g, yüksek puan ise düşük duyarlılı̆g 1 göstermektedir (Pekcan 2007; Tosun 2005). ADA'nın Türk toplumuna uyarlanması için geçerlik-güvenirlik çalışması Hale Tosun tarafindan 2005 yılında yapılmış ve Cronbach Alpha değeri 0.84 olarak bulunmuştur.

\section{Araştırmanın Etik Yönü}

Araştırmanın yürütülebilmesi için etik açıdan uygunluğu Kocaeli Üniversitesi Tıp Fakültesi Hastanesi Klinik Araştırmalar Etik Kurulu'nda değerlendirilerek onaylandı ve Sağlık Bakanlığı Türkiye Kamu Hastaneleri Kurumu'ndan, Yalova Kamu Birliği Hastaneler Kurumu'ndan, Özel Yalova Hastanesi ve Özel Atakent Hastanesi Müdürlükleri'nden yazılı izinler alındı. Araştırmanın örneklemini oluşturan hemşirelere çalışmanın amac1, süresi ve kendilerinden ne beklenildiği açıklanarak isteklilik, gönüllülük ilkesi doğrultusunda bilgilendirilmiş izinleri alındı.

\section{Verilerin Analizi}

Araştırma sonucunda elde edilen verilerin istatistiksel analizleri bilgisayar ortamında SPSS 15.0 (Statistical Package for Social Science for Windows) paket programı kullanılarak gerçekleştirildi. İstatistiksel analizlerde; gruplandırılmış değişkenlerin frekans ve yüzdelik değerleri, say1sal değişkenlerin aritmetik ortalama, standart sapma, minimum ve maksimum değerleri hesaplandi. Kategorik verilerin birbiriyle ilişkisini görmek için çapraz tablolar kullanıldı. İki grup ortalaması için Mann Whitney U testi, İkiden fazla grup ortalamasını karşılaştırmak için Kruskall
Wallis testi kullanıldı. Veri analizinden elde edilen sonuçlar \%95'lik güven aralığında anlamlılık $\mathrm{p}<0,05$ düzeyinde değerlendirildi (Durmuş 2011).

\section{BULGULAR}

Hemşirelerin bireysel ve mesleki özellikleri incelendiğinde; \%50,6'sının 25-34 yaş grubunda (yaş ortalama$\mathrm{s} 1=32 \pm 7,41), \% 54,1$ 'inin lisans mezunu olduğu saptand. Hemşirelerin mesleki deneyim yıllarının en fazla 11-15 y1l arasında olduğu (\%76,4), \%91,2'sinin servis hemşiresi olarak çalıştığı görüldü.

Hemşirelerin, 7 değer alanına göre kişisel değer seçimlerinin dağılımı incelendiğinde; birinci değer tercihi olarak $(\% 28,2)$ siyasi değerleri tercih ettiği görüldü. Hemşirelerin ikinci değer tercihi olarak sıklıkla $(\% 28,2)$ ahlaki değerleri, üçüncü olarak $(\% 22,9)$ dini değerleri, dördüncü olarak $(\% 20,0)$ sosyal değerleri, beşinci $(\% 25,3)$ ve altıncı $(\% 23,5)$ olarak iktisadi değerleri tercih ettiği ve yedinci değer seçiminin de yine $(\% 23,5)$ sosyal değerler olduğu saptandı (Tablo 2).

Çalışma kapsamındaki hemşirelerin yaş gruplarına göre kişisel değer seçimleri incelendiğinde; 15-24 yaşları arasındaki hemşirelerin ahlaki (\%30), 25-44 yaşları arasındaki hemşirelerin siyasi $(\% 61,9), 45$ ve üzeri yaşlarda bulunan hemşirelerin ise benzer oranlarda ahlaki ve dini $(\% 33,3)$ değerleri sıklıkla temel değer olarak benimsedikleri görüldü. Hemşirelerin yaş gruplarına göre değer seçimleri karşılaştırıldığında istatistiksel olarak anlamlı bir farklılık olmadığ saptandı $(\mathrm{p}>0,05)$ (Tablo 3).

Tablo 2. Hemşirelerin Kişisel Değer Seçimlerinin Dağılımı (N=170)

\begin{tabular}{|c|c|c|c|c|c|c|c|c|c|c|c|c|c|c|}
\hline \multirow{2}{*}{$\begin{array}{l}\text { Değer } \\
\text { Türü }\end{array}$} & \multicolumn{2}{|c|}{ Estetik } & \multicolumn{2}{|c|}{ Ahlaki } & \multicolumn{2}{|c|}{ Teorik } & \multicolumn{2}{|c|}{ İktisadi } & \multicolumn{2}{|c|}{ Dini } & \multicolumn{2}{|c|}{ Siyasi } & \multicolumn{2}{|c|}{ Sosyal } \\
\hline & $\mathbf{n}$ & $\%$ & n & $\%$ & n & $\%$ & n & $\%$ & n & $\%$ & $\mathbf{n}$ & $\%$ & $\mathbf{n}$ & $\%$ \\
\hline 1. Değer & 18 & 10,6 & 39 & 22,9 & 19 & 11,2 & 24 & 14,1 & 12 & 7,1 & 48 & 28,2 & 10 & 5,9 \\
\hline 2. Değer & 16 & 9,4 & 48 & 28,2 & 22 & 12,9 & 18 & 10,6 & 19 & 11,2 & 27 & 15,9 & 20 & 11,8 \\
\hline 3. Değer & 21 & 12,4 & 27 & 15,9 & 26 & 15,3 & 15 & 8,8 & 39 & 22,9 & 14 & 8,2 & 28 & 16,5 \\
\hline 4. Değer & 21 & 12,4 & 33 & 19,4 & 23 & 13,5 & 23 & 13,5 & 24 & 14,1 & 12 & 7,1 & 34 & 20,0 \\
\hline 5. Değer & 29 & 17,1 & 16 & 9,4 & 18 & 10,6 & 43 & 25,3 & 18 & 10,6 & 17 & 10,0 & 29 & 17,1 \\
\hline 6. Değer & 18 & 10,6 & 15 & 8,8 & 20 & 11,8 & 40 & 23,5 & 28 & 16,5 & 23 & 13,5 & 26 & 15,3 \\
\hline 7. Değer & 23 & 13,5 & 18 & 10,6 & 30 & 17,6 & 23 & 13,5 & 14 & 8,2 & 22 & 12,9 & 40 & 23,5 \\
\hline
\end{tabular}




\begin{tabular}{|c|c|c|c|c|c|c|c|c|c|c|c|c|c|c|c|c|c|c|c|}
\hline \multicolumn{2}{|c|}{ 芝 } & \multicolumn{4}{|c|}{$\begin{array}{l}\hat{0} \\
\frac{0}{0}\end{array}$} & \multicolumn{3}{|c|}{$\begin{array}{l}* \\
\stackrel{*}{0} \\
0 \\
0\end{array}$} & \multicolumn{3}{|c|}{$\begin{array}{l}\stackrel{*}{\widetilde{\delta}} \\
\stackrel{\delta}{\delta}\end{array}$} & \multicolumn{5}{|c|}{$\stackrel{*}{\stackrel{*}{0}}$} & \multicolumn{3}{|c|}{$\begin{array}{l}\mathbb{Z} \\
\stackrel{0}{0} \\
0\end{array}$} \\
\hline \multirow{2}{*}{ 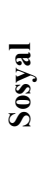 } & $a^{\circ}$ & $n$ & ma & $\approx$ & 0 & గ్ర & 0 & 0 & $\vec{a}$ & $\stackrel{\square}{\curvearrowleft}$ & 0 & $\vec{b}_{0}$ & $\begin{array}{l}0 \\
\stackrel{5}{\circ}\end{array}$ & $N$ & 0 & 0 & 0 & $\vec{a}$ & $\begin{array}{l}\infty \\
i\end{array}$ \\
\hline & $=$ & - & $\infty$ & - & 0 & 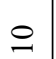 & 0 & 0 & $n$ & in & 0 & $m$ & 6 & - & 0 & 0 & 0 & - & $a$ \\
\hline \multirow{2}{*}{$\overbrace{\bar{n}}^{\bar{s}}$} & $\partial^{\circ}$ & $\stackrel{\sim}{\sim}$ & $\overline{\mathbf{a}}$ & $\stackrel{\infty}{\infty}$ & 0 & $\stackrel{\sim}{\sim}$ & $\varnothing$ & ి & $\hat{\theta}$ & $\stackrel{\sim}{\sim}$ & 0 & m & "ֶ. & "ñ & $\ddot{N}$ & $\approx$ & 0 & ठ্ঠ & tô \\
\hline & $=$ & $\sigma$ & $\mathscr{2}$ & 2 & 0 & f & $\infty$ & 0 & $\Xi$ & $\approx$ & 0 & 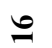 & $a$ & $\cong$ & $r$ & $m$ & 0 & $\nabla$ & $\exists$ \\
\hline \multirow{2}{*}{ 节 } & $\partial^{\circ}$ & in & $\stackrel{n}{n}$ & $\stackrel{m}{\varrho}$ & $\stackrel{m}{m}$ & $\stackrel{n}{\sim}$ & 0 & 0 & $\hat{\varrho}$ & $\tilde{\sigma}^{n}$ & 0 & $\stackrel{m}{\leftarrow}$ & $\overrightarrow{\mathrm{i}}$ & $\tilde{\infty}^{1}$ & $\hat{0}$ & $\hat{\sigma}$ & 0 & 0 & $\therefore$ \\
\hline & $=$ & - & $n$ & 0 & $\sim$ & $\simeq$ & 0 & 0 & 6 & 0 & 0 & $N$ & - & $\nabla$ & $m$ & $\sim$ & 0 & 0 & $\simeq$ \\
\hline \multirow{2}{*}{ 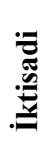 } & $\partial^{\circ}$ & 으 & $\Xi$ & $\begin{array}{l}n \\
n\end{array}$ & $\widehat{\widehat{0}}$ & 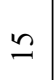 & 0 & 8 & $\underset{\sim}{0}$ & $\tilde{\sim}$ & 0 & $\vec{i}$ & $\begin{array}{l}0 \\
=\end{array}$ & $\overbrace{0}^{m}$ & $\stackrel{\vec{N}}{\vec{N}}$ & $\approx$ & 0 & $\vec{a}$ & $\begin{array}{l}\infty \\
\underset{ \pm}{ \pm}\end{array}$ \\
\hline & $=$ & $N$ & $\simeq$ & $a$ & - & $\stackrel{\Xi}{\sim}$ & 0 & $a$ & 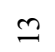 & $\sim$ & 0 & - & 0 & $\infty$ & 0 & $m$ & 0 & - & $\tilde{v}$ \\
\hline \multirow{2}{*}{ 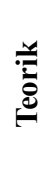 } & $\partial^{\circ}$ & $\cong$ & $\begin{array}{l}\infty \\
\stackrel{1}{\simeq}\end{array}$ & $\begin{array}{l}0 \\
\infty\end{array}$ & 0 & $\stackrel{n}{=}$ & 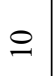 & 0 & 0 & $\stackrel{ \pm}{\stackrel{ \pm}{I}}$ & 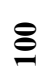 & $\stackrel{m}{\vec{\sim}}$ & $\stackrel{\infty}{=}$ & $\sim$ & $\stackrel{m}{ \pm}$ & 0 & $\approx$ & $\stackrel{\sim}{\infty}$ & $\stackrel{m}{0}$ \\
\hline & $=$ & $m$ & $=$ & in & 0 & $\stackrel{\infty}{\sim}$ & - & 0 & 0 & $\stackrel{0}{-}$ & $m$ & 은 & $\nabla$ & - & $\nabla$ & 0 & - & N & $\stackrel{0}{0}$ \\
\hline \multirow{2}{*}{$\frac{\frac{\pi}{4}}{\frac{\pi}{\pi}}$} & $\partial^{\circ}$ & లి & $\begin{array}{l}0 \\
\ddot{\sim}\end{array}$ & $\begin{array}{l}\cong \\
\cong\end{array}$ & ले & $\begin{array}{l}\infty \\
\hat{\sim}\end{array}$ & 으 & in & $\stackrel{\sim}{0}^{\infty}$ & $\stackrel{\vec{\oplus}}{\dot{m}}$ & 0 & $\begin{array}{l}\tilde{n} \\
\ddot{n}\end{array}$ & $\begin{array}{l}0 \\
\stackrel{\sim}{N}\end{array}$ & 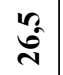 & $\hat{\varrho}$ & $\stackrel{m}{m}$ & in & $\stackrel{\sim}{\infty}$ & $\begin{array}{l}0 \\
\text { î }\end{array}$ \\
\hline & $=$ & 0 & $\approx$ & $a$ & $N$ & $\underset{m}{\infty}$ & - & - & $\stackrel{0}{ }$ & $\stackrel{\infty}{\sim}$ & 0 & $\simeq$ & $r$ & $\mathscr{2}$ & $m$ & $\nabla$ & $N$ & $\sim$ & $\ddot{m}$ \\
\hline \multirow{2}{*}{ 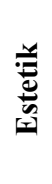 } & $\partial^{\circ}$ & $\cong$ & 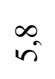 & $\begin{array}{l}n \\
n\end{array}$ & $\hat{\sigma}$ & $\stackrel{m}{=}$ & 0 & 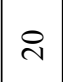 & $\stackrel{m}{\sim}$ & $\hat{\circ}$ & 0 & ఫुڤ & $\overrightarrow{\mathrm{i}}$ & $\begin{array}{l}\vec{\infty} \\
\underset{\infty}{-}\end{array}$ & $\hat{\Sigma}$ & 0 & 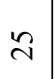 & $\vec{a}$ & $\stackrel{m}{0}$ \\
\hline & $=$ & $m$ & in & $a$ & - & $\stackrel{\infty}{\sim}$ & 0 & $\nabla$ & $\nabla$ & 으 & 0 & $m$ & - & $a$ & $n$ & 0 & - & - & $\stackrel{0}{0}$ \\
\hline & \multirow[t]{2}{*}{ 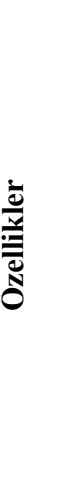 } & 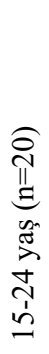 & 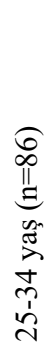 & 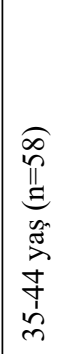 & 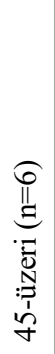 & 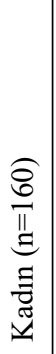 & 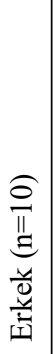 & 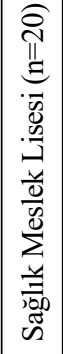 & 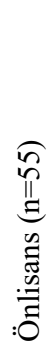 & 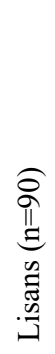 & 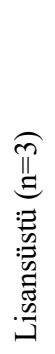 & 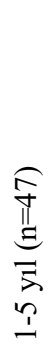 & $\begin{array}{l}\underset{f}{f} \\
\mathbb{\|} \\
\Xi \\
\vec{\Xi} \\
0 \\
0 \\
b\end{array}$ & 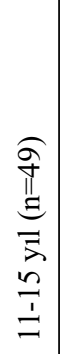 & 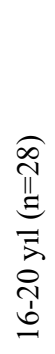 & 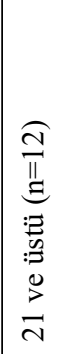 & 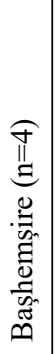 & 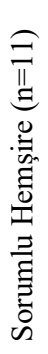 & 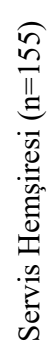 \\
\hline & & \multicolumn{4}{|c|}{$\underset{\star}{\approx}$} & & 总 & & \multicolumn{4}{|c|}{ 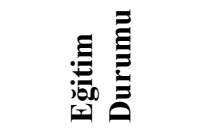 } & \multicolumn{4}{|c|}{ 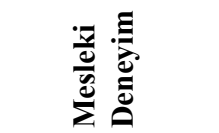 } & \multicolumn{3}{|c|}{ نَّ } \\
\hline
\end{tabular}


Hemşirelerin eğitim durumuna göre temel değer tercihleri incelendiğinde; sağlık meslek lisesi mezunlarının (\%45) iktisadi, önlisans mezunlarının (\%30) siyasi, lisans mezunlarının $(\% 30,4)$ ahlaki ve lisansüstü eğitime sahip hemşirelerin ise tamamının $(n=3)$ teorik değerleri temel olarak benimsedikleri görüldü. Hemşirelerin eğitim durumlarına göre temel değer seçimleri karşılaştırıldığında da istatistiksel olarak anlamlı farkl1lık olduğu belirlendi $(\mathrm{p}<0,05)$ (Tablo 3$)$.

Hemşirelerin mesleki deneyim yıllarına göre temel değer tercihleri incelendiğinde; 1-5 y1l (\%34), 6-10 y1l $(\% 26,5)$ ve $16-20$ y1l $(\% 25)$ deneyimi olan hemşirelerin siyasi, $11-15$ y1l arası deneyimi $(\% 26,5)$ olanların hem siyasi hem de ahlaki, 21 yıl ve üstü $(\% 33,3)$ mesleki deneyime sahip hemşirelerin ise ahlaki değerleri sıklıkla benimsediği görüldü. Mesleki deneyim yılına göre hemşirelerin temel değer tercihleri karşılaştırıldığında da istatistiksel olarak anlamlı farklılık saptand 1 $(\mathrm{p}<0,05)$ (Tablo 3).

Hemşirelerin yaptıkları göreve göre temel değer tercihleri incelendiğinde; başhemşirelerin $(\% 50,0)$ ahlaki, hem servis $(\% 28,4)$, hem de sorumlu hemşirelerin $(\% 36,4)$ siyasi değerleri sıklıkla temel değer olarak seçtiği ve görevlerine göre hemşirelerin temel değer tercihleri karşılaştırıldığında da istatistiksel olarak anlamlı bir farklılık bulunmadığı saptandı $(\mathrm{p}>0,05)$ (Tablo 3).

Hemşirelerin etik duyarlılık düzeylerine ilişkin puan ortalamaları incelendiğinde toplam ADA puan ortala-

Tablo 4. Hemşirelerin ADA ve Alt Boyutları Puan Ortalama$\operatorname{lar} 1(\mathrm{~N}=170)$

\begin{tabular}{|l|c|c|}
\hline ADA ve Alt Boyutları & Min-Max & Ort \pm SS \\
\hline Otonomi & $9-30$ & $17,74 \pm 4,61$ \\
\hline Yarar Sağlama & $5-23$ & $11,90 \pm 4,32$ \\
\hline Bütüncül Yaklaşım & $6-22$ & $12,61 \pm 4,17$ \\
\hline Çatışma & $3-15$ & $6,74 \pm 2,65$ \\
\hline Uygulama & $4-17$ & $9,59 \pm 2,99$ \\
\hline Oryantasyon & $4-18$ & $9,87 \pm 3,90$ \\
\hline Toplam ADA & $44-129$ & $76,33 \pm 22,84$ \\
\hline
\end{tabular}

\begin{tabular}{|c|c|c|c|c|c|c|c|c|}
\hline \multicolumn{2}{|c|}{$=$} & $\stackrel{*}{\stackrel{0}{0}}$ & $\stackrel{*}{\tilde{0}}$ & 蒿 & 浐 & $\begin{array}{l}\stackrel{n}{a} \\
\tilde{0}\end{array}$ & 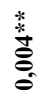 & : \\
\hline \multicolumn{2}{|c|}{ 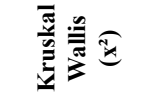 } & ثั & $\stackrel{\text { I }}{\stackrel{2}{2}}$ & 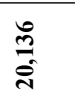 & $\begin{array}{l}\text { î } \\
\text { wy }\end{array}$ & $\stackrel{m}{m}$ & $\underset{\vec{i}}{\stackrel{\vec{\lambda}}{r}}$ & ڤ్ \\
\hline \multirow{2}{*}{ 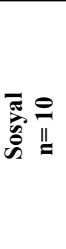 } & $\begin{array}{l}\text { w } \\
\text { 苦 } \\
0\end{array}$ & 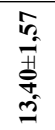 & 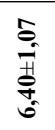 & 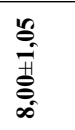 & $\begin{array}{l}R \\
\hat{0} \\
\hat{0} \\
\text { B. } \\
\text { r. }\end{array}$ & $\begin{array}{l}\hat{\infty} \\
0 \\
\vec{H} \\
\infty \\
i \\
i\end{array}$ & 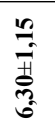 & 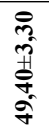 \\
\hline & 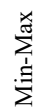 & $\stackrel{\varrho}{I}$ & $\begin{array}{l}\infty \\
i \\
i\end{array}$ & $\hat{b}$ & in & $\frac{9}{7}$ & i⿱口 & $\begin{array}{l}\text { in } \\
\text { of }\end{array}$ \\
\hline \multirow{2}{*}{ 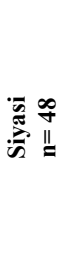 } & $\begin{array}{l}\text { के } \\
\text { 莘 }\end{array}$ & 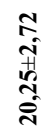 & 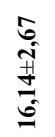 & 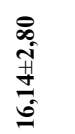 & 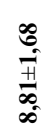 & 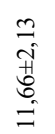 & 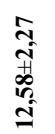 & 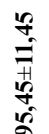 \\
\hline & 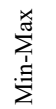 & 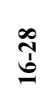 & శి & สุ & $\frac{10}{16}$ & $\overrightarrow{\bar{\infty}}$ & $\frac{\infty}{b}$ & $\frac{2}{\pi}$ \\
\hline \multirow{2}{*}{ 츨 } & $\begin{array}{l}\text { n } \\
\text { 营 } \\
0\end{array}$ & 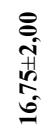 & 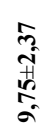 & 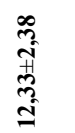 & 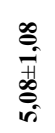 & 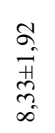 & $\begin{array}{c}8 \\
\stackrel{+}{+} \\
\hat{n} \\
\infty \\
\infty\end{array}$ & $\begin{array}{l}3 \\
0 \\
0 \\
4 \\
0 \\
50\end{array}$ \\
\hline & 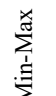 & $\begin{array}{l}\bar{I} \\
\text { J }\end{array}$ & $\frac{0}{b}$ & $\frac{1}{a}$ & f & $\frac{m}{i}$ & $\frac{m}{b}$ & $\begin{array}{l}\text { oे } \\
\text { ț }\end{array}$ \\
\hline \multirow{2}{*}{ 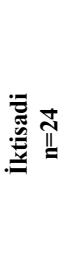 } & $\begin{array}{l}n \\
0 \\
0 \\
0\end{array}$ & 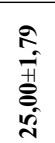 & $\begin{array}{l}\text { fo } \\
\text { से } \\
\text { जे }\end{array}$ & 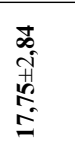 & 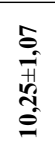 & $\begin{array}{l}\overrightarrow{\sigma_{0}} \\
\vec{H} \\
\vec{H} \\
\vec{g}\end{array}$ & 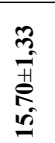 & 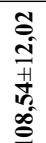 \\
\hline & 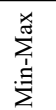 & ల్లి & $\frac{9}{ \pm}$ & जे & $\stackrel{\sim}{\infty}$ & $\frac{n}{\stackrel{n}{I}}$ & $\frac{\infty}{\unlhd}$ & $\frac{m}{=}$ \\
\hline \multirow{2}{*}{ 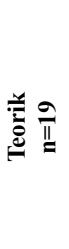 } & $\begin{array}{l}\text { w } \\
\text { 营 }\end{array}$ & 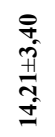 & $\begin{array}{l}\frac{F}{4} \\
\text { 永 } \\
\infty\end{array}$ & $\begin{array}{l}\text { ते } \\
\text { जे } \\
\text { जे }\end{array}$ & 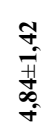 & 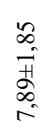 & 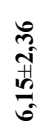 & 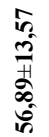 \\
\hline & 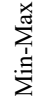 & สุ & $\frac{\pi}{b}$ & $\frac{0}{11}$ & $\stackrel{\infty}{\infty}$ & $\stackrel{\vec{n}}{\vec{n}}$ & $\underset{7}{7}$ & $\frac{a}{\dot{j}}$ \\
\hline \multirow{2}{*}{ 童 } & $\begin{array}{l}\text { n } \\
\text { 菩 }\end{array}$ & 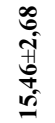 & $\begin{array}{l}8 \\
\mathbb{1} \\
+ \\
\infty \\
\infty \\
\infty\end{array}$ & 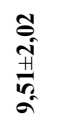 & $\begin{array}{l}\text { oे } \\
\text { 离 } \\
\text { in }\end{array}$ & 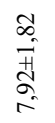 & 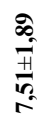 & $\begin{array}{l}\frac{\infty}{0} \\
\frac{1}{0} \\
\infty \\
0 \\
0\end{array}$ \\
\hline & 竞 & $\stackrel{\stackrel{I}{I}}{\cong}$ & $\frac{0}{b}$ & $\frac{a}{b}$ & $\frac{9}{m}$ & $\frac{m}{7}$ & $\frac{\pi}{7}$ & $\frac{\infty}{\frac{\infty}{1}}$ \\
\hline \multirow{2}{*}{ 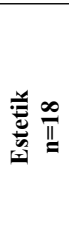 } & $\begin{array}{l}w \\
\text { 萻 } \\
0\end{array}$ & \begin{tabular}{l}
$\infty$ \\
0 \\
\multirow{0}{*}{} \\
0 \\
0
\end{tabular} & 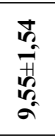 & 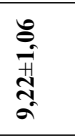 & 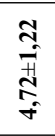 & 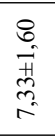 & مُ & 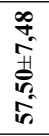 \\
\hline & 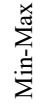 & $\stackrel{9}{I}$ & $\frac{m}{i}$ & $\frac{7}{1}$ & ले & $\stackrel{m}{\vec{n}}$ & $\overline{7}$ & $\begin{array}{l}\stackrel{0}{\$} \\
\stackrel{1}{\infty}\end{array}$ \\
\hline 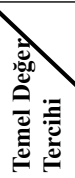 & & 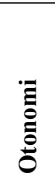 & 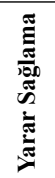 & 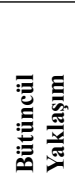 & 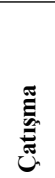 & 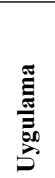 & 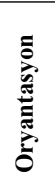 & 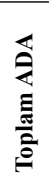 \\
\hline
\end{tabular}


masinın $76,33 \pm 22,84$, otonomi alt boyutu puan ortalamasının $17,74 \pm 4,61$; yarar sağlama alt boyutu puan ortalamasının $11,90 \pm 4,32$; bütüncü yaklaşım alt boyutu puan ortalamasının $12,61 \pm 4,17$; çatışma alt boyutu puan ortalamasinin $6,74 \pm 2,65$; uygulama alt boyutu puan ortalamasinın $9,59 \pm 2,99$ ve oryantasyon alt boyutu puan ortalamasının ise $9,87 \pm 3,90$ olduğu saptandi (Tablo 4).

Hemşirelerin temel değer türlerine göre ADA ve alt boyutlarından aldıkları puanlar karşılaştırıldığında; sosyal değerleri benimseyen hemşirelerin otonomi $\left(x^{2}=20,016 ; p<0,05\right)$, yarar sağlama $\left(x^{2}=13,126\right.$; $p<0,05)$, bütüncül yaklaşım $\left(x^{2}=20,136\right.$; $\left.p<0,01\right)$, çatışma $\left(x^{2}=25,237 ; p<0,01\right)$, oryantasyon $\left(x^{2}=23,74\right.$; $\mathrm{p}<0,01)$ alt boyutları ile toplam $\operatorname{ADA}\left(\mathrm{x}^{2}=32,012\right.$; $\mathrm{p}<0,01)$ puan ortalamalarının diğer değer türlerini temel değer olarak tercih eden hemşirelere göre daha düşük olduğu ve bu farklılığın da istatistiksel olarak anlamlılık gösterdiği saptandı (Tablo 5).

\section{TARTIŞMA}

Çalışma kapsamına alınan hemşirelerin \%28,2'sinin temel değer tercihi olarak siyasi değerleri seçmiş oldukları belirlenmiştir. 25-44 yaş gurubunda bulunan hemşirelerin ve servis hemşiresi olarak çalışmakta olan hemşirelerin en sik tercih ettikleri değerin siyasi değerler olduğu saptanmıştır. Siyasi değerlerin genel yapısı incelendiğinde; belirgin amacı güç elde etmek olan ve yönetici olabilmek amacı ile çeşitli yollar izleyen ve ilerleme firsatları arayan bireylerin temelde sahip oldukları değer türü olduğu görülmektedir (Babadağ 2010; Öztürk 2010). Çalışma örneklemindeki hemşirelerin çoğunluğunun lisans mezunu, genç yaş grubunda ve servis hemşiresi olarak görev yaptığı dikkate alındığında var olan statülerini yükseltmek, yönetici olabilmek gibi nedenlerle hemşirelerin bu değer türünü seçmeleri beklenilen bir durum olarak düşünülebilir. Ayrıca Rassin (2008) hemşirelerin temel değerlerini incelediği çalışmasında öncelikli 3 temel değeri; aile güvenliği, mutluluk ve başarı duygusu olarak saptamıştır; istikrar ve güvene değer veren insanların ekonomik istikrar sağlayacak meslekleri seçme eğilimin- de olduklarını belirtmiş̧tir. Bu anlamda değerlendirildiğinde hemşirelerin siyasi değerleri istikrar ve kendilerini güvende hissetmek amacı ile tercih ettikleri sonucu çıkartılabilir.

Bulut ve İşman (2004)'ın sağlık yöneticileri ile yaptığı benzer bir çalışmada ise kişisel değerlerin teorik, sosyal, politik ve estetik değerler olarak önemine göre sıralandığı görülmüştür. Bu çalışmanın hemşirelerin yanı sıra hekimleri de kapsamasının ve sadece yöneticiler ile gerçekleştirilmesinin bizim çalışma bulgularımızdan farklılık göstermesine neden olduğu düşünülebilir. Sar1 (2005)'nın, “Değerler Hiyeraraşisi Ölçeği'ni kullanarak öğretmen adaylarının değer tercihlerini belirlemek amacıyla yaptığ 1 çalışmada ise öğretmen adaylarının önem verdikleri değerler sırasıyla; siyasi, ahlak, dini, iktisadi, estetik, sosyal ve teorik değerler olarak belirlenmiştir Bu çalışmada ilk üç sırada yer alan değer tercihleri ile araştırma bulgularımız benzerlik göstermektedir. Hemşirelere bakımı olumlu yönde etkileyen kişisel değerlerini fark ederek bu temel değerlerin üzerine profesyonel değerleri kazandırarak hemşirelerin etik duyarlılık düzeyleri ve bakım kalitesi yükseltilebilir (Acaroğlu 2003; Babadağ 2010).

Siyasi değerleri benimseyen hemşireler bu değerler doğrultusunda kısa zamanda eyleme geçmeyi disiplin üyeleri ile birleşerek güç oluşturmayı, gücünü gerektiğinde atılganlıkla kullanmayı hedefleyen tutumlar sergiler (Babadağ 2010).

$\mathrm{Bu}$ literatür bilgisi ile değerlendirildiğinde; hemşirelerin ilk sırada siyasi değerleri seçmiş olmaları hemşirelikte güç oluşturma ve gerektiğinde kullanma adına olumlu olabileceği düşünülebilir. Çalışma kapsamında estetik ve teorik değerlerin yedi değer türü içinde en az tercih edilen değer türü olduğu saptanmıştır. Babadağ (2010) estetik değerlere sahip hemşirelerin daha duyuşsal olduğunu, yaratıcılığa öncelik verdiğini, etiğe ve estetiğe ilgi duyduklarını belirtmektedir. Teorik değerlere sahip hemşirelerin ise mantıksal düşünme, veri toplama ve çözüm üretme gibi konulara ilgi duyduğunu bildirmektedir. Bu iki değer türünün, hemşire- 
lik bakımında bilimsel problem çözme yaklaşımının kullanılması, etiğe ilgi duyulması gibi hemşirelik bakımının kalitesini artırmak adına önemini dikkate ald1$\breve{g}$ ımızda temel değer tercihleri içinde en az tercih edilen değerler olması hemşirelik eğitiminde bu konuda gereksinim olduğunu göstermektedir. Değer sisteminin bir bütün olduğunu düşünülürse hemşirelik öğrencileri daha önceden sahip oldukları bireysel değerler üzerine eğitimleri süresince profesyonel değerleri ekleyerek bir değer sistemi oluşturacaklardır. Hemşirelik eğitiminde öğrencilerin bakımın kalitesini artıracak kişisel değerlerinin farkındalığının artırılması, bu değerlerin ön plana çıkarılması ve profesyonel değerlerin kazandırılması gerekmektedir. Hemşirelerin profesyonel değerleri hemşirelerin bakım eylemlerini uygulamalarında, kararlarında ve etik sorunları çözümlemelerine rehberlik ederken aynı zamanda sağlıklı/ hasta bireyler, meslektaşları, diğer ekip üyeleri ve toplum ile etkileşimlerine de rehberlik ederler (Acaroğlu 2014).

Hemşirelerin etik duyarlılık düzeylerine bakıldığında çalışmada elde edilen sonuçlar Tosun (2005)'un yapmış olduğu çalışmada hemşirelerin otonomi, yarar sağlama, bütüncül yaklaşım, oryantasyon alt boyutlarında yüksek etik duyarlılığa sahip olmaları ile benzerlik göstermektedir. Yüksek etik duyarlılığa sahip olan hemşireler etik sorunların varlığını çok daha kolay fark edip, doğru kararlar almaktadırlar (Başak, Uzun ve Arslan 2010). Çalışmada toplam ADA, çatışma ve uygulama alt boyutlarında ise Tosun (2005)'un çalışmasına göre daha yüksek duyarlılık saptanmıştır. $\mathrm{Bu}$ farklılığın olması ise araştırmanın küçük bir il s1nırları içinde görev yapan hemşireler ile gerçekleştirilmesi ve onların etik sorunların yaşandığı vakalar ile daha az karşılaşma olasılıklarından kaynaklanabileceği düşünülmüştür.

Hemşirelerin temel değer tercihlerine göre etik duyarlılık düzeyleri karşılaştırıldığında; otonomi, yarar sağlama bütüncü yaklaşım, çatışma ve oryantasyon alt boyutları ile ADA toplamında anlamlı farkl1lıklar görülmüştür $(p<0,05)$. Çalışma kapsamındaki hemşirelerin genel olarak etik duyarlılık düzeylerine bakıldığın- da (toplam ADA) sosyal değerleri temel olarak benimseyen hemşirelerin en yüksek, iktisadi değerlere sahip hemşirelerin ise en düşük etik duyarlılık düzeyine sahip oldukları görülmüştür. Babadağ (2010)'a göre; ekonomik değerlere sahip hemşireler iş saati bitiminde hizmeti sonlandırma, eve gidince çalışma ortamındaki sorunları aklından çıkarma ve ilgisini bulunduğu ortam/kişilere yöneltme gibi davranışlar sergilerken sosyal değerlere sahip hemşireler önceliği hastasının ve diğerlerinin gereksinimlerinde yoğunlaştıran, ücret veya yorgunluğa ya da fazladan harcayacağı zamana önem vermeden, bireye daha iyi bakım vermeyi, onun için gerekli tüm koşulları sağlamayı, daha iyi ilişkiler kurmayı hedefleyen davranışlar sergiler. $\mathrm{Bu}$ bilgiler 1şığında değerlendirildiğinde sosyal değerlere sahip hemşirelerin yüksek etik duyarlılık düzeyleri göstermesinin beklenen bir sonuç olduğu söylenebilir.

Bulut ve İşman (2004)'in, çalışmasında da sosyal değerler ile politik değerler arasında negatif ve güçlü, estetik değerler ile ekonomik değerler arasında da negatif ve orta derecede korelasyon bulunmuştur ve araştırma sonuçlarımız Bulut ve İşman'ın çalışmasına paralellik göstermektedir.

\section{SONUÇ VE ÖNERILER}

Hemşirelerin değer tercihlerinin sıklıkla siyasi ve ahlaki değerler olduğu, estetik değerlerin ilk 7 değer tercihi arasında yer almadığı görüldü. Hemşirelerin etik duyarlılık düzeylerinin iyi olduğu görüldü. Hemşirelerin benimsedikleri kişisel değerlere göre etik duyarl11ık düzeylerinin farklı1ık gösterdiği sosyal değerleri benimseyen hemşirelerin en yüksek etik duyarlılığa sahip olduğu saptandi.

Etik duyarlılığı olumlu yönde etkileyen sosyal, teorik ve estetik değerlerin hemşirelik öğrencilerine kazandırılmasına ve güçlendirilmesine yönelik eğitim içeriklerinin düzenlenmesi ve hemşirelerde kişisel değer seçimleri ve etik duyarlılık düzeylerini daha geniş örneklem gruplarında ve farklı değişkenler ile test eden araştırmalar yapılarak hemşirelik literatürüne veri oluşturulması önerildi. 


\section{Hemşirelerin Kişisel Değerleri ile Etik Duyarlılıkları Arasındaki İliş̧kinin Belirlenmesi}

\section{KAYNAKLAR}

Acaroğlu, R. (2003). Bakımda Etik. II. Uluslararası IX. Ulusal Hemşirelik Kongresi, 7-11 Eylül, Antalya.

Acaroğlu, R. (2014). Revize Edilen Hemşirelerin Mesleki Değerleri Ölçeği Türkçe formunun güvenirlik ve geçerliği. Ístanbul Üniversitesi Florence Nightingale Hemşirelik Dergisi, 22(1): 8-16.

Acaroğlu, R., Şendir, M. (2012). Bireyselleştirilmiş bakımı değerlendirme skalaları. İstanbul Üniversitesi Florence Nightingale Hemşirelik Dergisi, 20(1): 10-16.

Aitamaa, E., Leino-Kilpi, H., Puukka, P., Suhonen, R. ( 2010). Ethical problems in nursing management: The role of codes of ethics. Nursing Ethics, 17(4): 469-482.

Aksu, T., Akyol, A. (2011). İzmir'deki hemşirelerin etik duyarlılıklarının incelenmesi. Türkiye Klinikleri Journal of Medical EthicsLaw and History, 19(1): 16-24.

Altun, İ. (2001). Kocaeli Sağlık Yüksekokulu Öğrencilerinin Kişisel Değerleri ve Meslek Seçimlerine Etki Eden Faktörler. 1. Uluslararas1 8. Ulusal Hemşirelik Kongresi, 29 Ekim-2 Kasım 2000, Antalya.

Aslan, Ö., Vural, H., Avcı, P. (2003). Ameliyathane hemşirelerinin etik sorunlara yönelik yaklaşımlarının belirlenmesi. Gülhane Tip Dergisi, 45(2): 147-152.

Babadağ, K. (2010). Hemşirelik ve Değerler. 1. basım, Alter Yayıncilik, Ankara.

Başak, T., Uzun, Ş., Arslan, F. (2010). Yoğun bakım hemşirelerinin etik duyarlılıklarının incelenmesi. Gülhane Tıp Dergisi, 52(1): 76-81.

Bulut, D., İşman, Ç. (2004). Muğla ili sağlık yöneticilerinde kişisel değer analizi. Hacettepe Sağllk İdaresi Dergisi, 7(3): 25-32.

Casterle, B., Izumi, S., Godfrey, N. S., Denhaerynck, K. (2008). Nurses' responses to ethical dilemmas in nursing practice: Metaanalysis. Journal of Advanced Nursing, 63(6): 540-549.

Cherie, A., Mekonen, A. H., Shimelse, T. (2005). Introduction to Professional Nursing and Ethics. The Ethiopia Public Health Training Initiative, Ethiopia.

Cozma, I. F. (2011). The relation between globalization and personal values across 53 countries and 28 years. $P h D$ thesis, University of Tennessee, Knoxville.

Dinç, L., Görgülü, R. S. (2002). Teaching ethics in nursing. Nursing Ethics, 9(3): 259-268.

Durmuş, B. (2011). Sosyal Bilimlere SPSS ile Veri Analizi. 4. basım, Beta Basım Yayım, İstanbul.

Elçigil, A. ve ark. (2011). Hemşirelerin karşılaştıkları etik ikilemlerin incelenmesi. Anadolu Hemşirelik ve Sağllk Bilimleri Dergisi, 14(2): 52-60.

Fry, S. T., Veatch, R. M., Taylor, C. (2010). Case Studies in Nursing Ethics. 4th ed., Jones Bartlett Learning, Washington.
Jormsri, P., Kunaviktikul, W., Ketefian, S., Chaowalit, A. (2005). Moral companente in nursing practice. Nursing Ethics, 12(6): 582594.

Karaöz, S. (2000). Cerrahi hemşireliği ve etik. C.Ü. Hemşirelik Yüksekokulu Dergisi, 4(1): 1-8.

Keskin, G., Yıldırım, G. A. (2006). Hemşirelerin kişisel değerlerinin ve iş doyumlarının incelenmesi. Ege Üniversitesi Hemşirelik Yüksekokulu Dergisi, 22(1): 119-133.

Korkmaz-Devrani, T. (2010). Kişisel değerlerin kuramsal yapısı ve pazarlamadaki uygulamalar. Eskişehir Osmangazi Üniversitesi IIBF Dergisi, 5(1): 49-70.

Lützen, K., Johansson, A., Nordström, G. (2000). Moral sensitivity: Some differences between nurses and physicians. Nursing Ethics, 7(6): 520-530.

Noureddine, S. (2001). Development of the ethical dimension in nursing theory. International Journel of Nursing Practice, 7(1): 2-7.

Ochsner, A. K. (1996). Development and validation of a self-report inventory for professional nursing values. PhD thesis, Texas Tech University, Texas.

Öztürk, H. (2010). Yönetici hemşirelerin etik davranışları ve bir araştırma. Yayınlanmamış Yüksek Lisans Tezi, İstanbul Üniversitesi Sosyal Bilimler Enstitüsü, Hastane ve Sağlık Kuruluşlarında Yönetim Bilim Dalı, İstanbul.

Pekcan, H. S. (2007). Yalova ili ve çevresinde görev yapan hekimlerin ve hemşirelerin etik duyarlılıkları. Yayınlanmamış Yüksek Lisans Tezi, Marmara Üniversitesi Sağlık Bilimleri Enstitüsü, İstanbul.

Rassin, M. (2008). Nurses' professional and personal values. Nursing Ethics, 15(5): 614-630.

Sarı, E. (2005). Öğretmen adaylarının değer tercihleri: Giresun Eğitim Fakültesi örneği. Değerler Eğitimi Dergisi, 3(10): 73-88.

Schneider, D. G., Ramos, R. S. (2012). Moral deliberation and nursing elements of methodological proposal. Nursing Ethics, 19(6): 764-778.

Şendir, M. (2012). Hemşirelik felsefesi. Atabek-Aşt1, T., Karadağ, A. (Ed). Hemşirelik Esasları/Hemşirelik Bilimi ve Sanatı. Akademi Basın ve Yayıncılık, İstanbul, 104-112.

Tel, H. (2012). Yoğun bakım ünitelerinde sık karşıllaş1lan etik sorunlar. Cumhuriyet Hemşirelik Dergisi, 1(1): 30-38.

Tosun, H. (2005). Sağlık bakım uygulamalarında deneyimlenen etik ikilemlere karşı hekim ve hemşirelerin duyarlılıklarının belirlenmesi. Yayınlanmamıs Doktora Tezi, İstanbul Üniversitesi Sağlık Bilimleri Enstitüsü, İstanbul.

Volker, D. L. (2012). Is there a unique nursing ethic? Nursing Science Quarterly, 16(3): 205-211. 